\title{
Interculturation and Catholicity as Keys for Interpretation
}

In the final two chapters of this study, we want to explore the contribution of the discourses in these three university cities in French-speaking Africa to broader debates in intercultural theology, and to the science and religion debate. This is grounded in convictions concerning the catholicity of the church and the catholicity of theology in that they are intended to speak to the whole church and the whole of humanity. Intercultural theology holds that theological reflection is on the one hand localized and embedded in particular social contexts (cf. Schreiter 1985), but on the other hand is part of a worldwide conversation with the global 'catholic' community of Christian communities (cf. Schreiter 1997). It is also catholic in the sense that it invites all of humanity to share in the grace it has discovered in the encounter with the triune God.

This study has confirmed the hypothesis that debates on the relationship between science and religion are geographically and culturally located. Yet, there is also a 'catholicity' to the worldwide scientific community that engages in international and intercultural conversations. Though scientific discoveries are always made in particular settings and embedded in historical traditions of research, they are presented to the world 'with universal intent' (Polanyi 1962). Given that both science and faith are catholic in scope, this is equally the case for the science and faith debate. Borrowing a term that has become common in intercultural theology, we want to propose that the science and religion debate is inexorably 'glocal': it is locally embedded, but it shares in 'global flows' (Schreiter 1997, 15ff) and engages in a global dialogue (Engelsviken 2011; Ott 2015; Küster 2016).

In the final chapter, we will concentrate on the contribution of the discourses studied to the broader science and faith debate. However, before we get there, in this chapter we focus on the contribution of this case study to the wider debates concerning the nature of the inculturation of Christian faith and theological discourse, and intercultural theology as a discipline. Both chapters are equally and consciously theological.

This chapter looks at how these discourses allow us to study what we might call 'the anatomy of inculturation' (cf. Magesa 2004). We recall two specific characteristics of our approach (as presented in Chapter 2) that will mark the further elaboration of this chapter the theological focus and the intercultural 
dynamics. In the first place, we underline the theological engagement of our perspective. 'Inculturation' is generally used in the literature to describe one main aspect of the contextualization process: the interaction between the Christian faith and local, cultural, and religious traditions (Bosch 1991, 447ff). The methodological tools of cultural anthropology and other social sciences are of great value for a theological study of inculturation, but theology adds its specific focus. "From the Christian theological perspective, inculturation is understood to be the process whereby the faith already embodied in one culture encounters another culture" (Magesa 2004, 17). In this definition it is the reference to 'faith' which makes it theological if faith is understood not only as a human religious phenomenon, but as the faith of the Christian community which has the self-revelation and salvific action of the triune God as its object, and is constantly in need of correction with regards to the question of how well it responds to this reality. Additionally, as we already argued in Chapter 2, the lived faith of the Christian communities is not understood as merely human but also as reflecting and revealing the work of the Holy Spirit. Secondly, we recall the broadening of the perspective from the contextual to the intercultural. Below, we will therefore argue that the term 'interculturation' better suits what is going on in the studied discourses from francophone Africa.

Therefore, in this chapter we relate the case study to the debate on in(ter) culturation and ask what this case study shows about the nature of these processes and what this implies for the understanding of intercultural theology. In the first part of this chapter we will provide a theoretical framework that enables the interpretation of the discourses. In most of the discourses the participants understood their engagement in the debate on science and religion as part of a complex interaction between Western science, African traditions, and Christian faith. Starting with the understanding of anthropologist Joel Robbins, we develop a framework that offers some important keys for the interpretation of this debate on cultures and influences. In the second part, building on this framework, we concentrate on a specific element of the influence of Western cultures and relate our findings to theories about what are called alternative modernities. The question of whether the discourses studied might point to such an alternative modernity is highly relevant to an intercultural approach to the science and religion questions: does Western modernity, in so far as it is deeply shaped by modern science and certain attitudes to science, represent the only or normative way of relating science and religion? It also has implications for the understanding of intercultural theology, which, as a discipline, is deeply embedded in the western academic context in which it developed (Ustorf 2011; Küster 2011, 110; Toren 2015c, 13off). In the 
final section, we will explore what insights the study of these intercultural exchanges evidenced in the discourses might contribute to our understanding of intercultural theology in general. We will argue that a catholic approach can do justice to the characteristics of interculturation as elaborated in this chapter.

\section{1 \\ From Inculturation to Interculturation and an Intercultural Theoretical Framework for Interpretation}

The study of this concrete example of the inculturation of Christian faith amongst university students and academics in French-speaking Africa offers unique insights into the inculturation process. As Laurenti Magesa has noted, theological studies of inculturation are often "largely theoretical, rarely benefitting from evidence gathered from empirical research" (Magesa 2004, 29). ${ }^{1}$ Of course, many of these contextual theological proposals are themselves forged through profound engagement with local communities, such as Vincent Donovan's account of his sustained theological dialogue with the Masai community (Donovan 1985; Bevans 2002, 64ff). Yet, they do not themselves present insight into the actual processes of inculturation in the wider community, as Magesa later provides for East Africa (Magesa 2004). Compared to Magesa, our study adds a layer of complexity. Where Magesa's empirical study focusses on the interaction between the Christian faith and African religious and cultural traditions, our context and interlocutors will add a third cultural component of Western modernity in the form of Western academic traditions. For the study of inculturation to be relevant today, this extra layer is crucial. Many of Benno's students from French-speaking Africa in Bangui (Central African Republic) found several proposals for African Christian inculturation theology alienating, because they seemed to contextualize the Christian faith in relation to a world that no longer exists. Such proposals mainly examined the question of how to contextualize the Christian faith in relation to Africa's pre-colonial cultural and religious traditions. For the students and academics in the university cities under consideration here, their African identity was crucial to them, but the traditional world of their grandparents sometimes felt strange, especially for those in Kinshasa. They looked for an inculturation of the faith in their

1 The otherwise very helpful overview of Steven Bevans Models of Contextual Theology (Bevans 2002) includes only normative theological proposals for how contextualization should happen. 
contemporary context as Africans with deep roots in pre-colonial traditions yet living in a rapidly urbanizing, modernizing, and globalizing culture.

\section{$2 \quad$ Understanding Interculturation}

Starting from the concept of inculturation, a term which is widely used, we argue that the process of appropriation is better described as 'interculturation', a term already introduced by others (Grenham 2001). The term 'inculturation' can suggest that one cultural reality is adapted to another, while the latter remains the same. The language of the inculturation process facilitates the image of Christian faith that is 'translated' into the language and thought forms of a receiving culture, while this culture fundamentally remains identical to itself, as in certain versions of a 'translation model' of contextualisation (Bevans 2002, 3 ff; cf. Toren 2015b). Or rather the reverse, Christ is seen as the 'transformer of culture' (Niebuhr 1951, 190-229) in a process in which the Christian message remains unchanged. As Martien Brinkman has shown, the encounter between the Christian message and a new cultural environment always leads to a 'double transformation' in which both realities are transformed (Brinkman 2009, 17-23). We think this process of mutual transformation is better captured in the term 'interculturation'. Furthermore, this term is better equipped to deal with the fact that there is not simply an encounter between two cultural realities. As we have seen, the participants not only mention Western (science) and African (tradition) but refer to a third influence as well: Christian (faith). In the next section, we elaborate on how these dynamics can be recognized in the discourses.

However, before we turn to the proper role of Christian faith in the interculturation process, we point to an important element of interculturation: its reflexivity. Henning Wrogemann is another author who, like Magesa, points to the importance of inculturation (or rather 'appropriation') processes as they actually happen and not only as missionaries and theologians believe they should happen (Wrogemann 2012, 279ff). He notes a contrast when he describes the missionary and theological discourse as reflexive, but inculturation by the local community as 'intuitive', or as happening, for example, through dreams and visions, as exemplified in African Independent Churches. It is true that much appropriation of the Christian message will happen intuitively, either through dreams or in much more down to earth ways, because the first generation of local evangelists and catechists understood the message of the missionaries in terms of their own cultural framework and transmitted it in ways they believed would make the most sense to their hearers (Sanneh 1983). However, local reception, is not just intuitive. 
In these dynamics, the Christian faith is indeed a factor of its own in this intercultural interaction. In Chapter 3, we already intimated, with reference to studies by Lamin Sanneh and others, that the cultural interaction between Europe and Africa in the modern era cannot be limited to the encounter between Western cultural imperialism and colonisation on the one hand, and African traditional cultures and society on the other. Though the Christian faith was mainly mediated through Western (European and European- American) voices, this gave African Christians access to the Bible, which, through translation, became their own and could be used to criticise culturally Western Christian traditions received through the missionaries (see Chapter 3).

However, what we have called 'Christian' (faith) should not be thought of as one culture among others. We believe that such a presentation would not do justice to the way Christian faith relates to culture, and such an understanding would also make an intercultural theological approach a very confusing enterprise. We think the cultural anthropologist Joel Robbins' explanation of the complex way Christian identity is related to culture offers an important step forward for the proper understanding of the role of Christian faith. In a recent article on conversion to Christianity amongst the Urapmin, a tribal group in Papua New Guinea, Robbins notes that the recently converted Urapmin Christians continue to engage in traditional practices that stand in tension with their newly acquired Christian faith, such as the sacrifice of a pig for the healing of a severely ill child. Although the Urapmin are themselves conscious of tensions in cultural practices, and though some of them would not agree with this practice, the traditional custom itself is reinterpreted from a Christian framework. Thus, the pig refers to the sacrifice of Christ and the offended spirits are not appeased and negotiated with but are rather bound and expelled. Below, in the context of hybridity, we will expand on Robbins' remark that what happens here can more adequately be described by "stronger, more 'modern-looking' models of culture - ones that see cultures as having a real role in shaping people's lives" (Robbins 2017, 37). We already referred to Robbins' position in Chapter 2.

These Urapmin Christians relate to their traditional culture in the light of their new Christian value system, and therefore integrate traditional practices in as far as they can find a way to reconcile them with their new faith. This does not mean that there are no tensions between their Christian faith and traditional practices, but that this tension is simply part of an ongoing conversion process: Christianity as a religion sets up 'duplex cultural formations' (Robbins 2017,40 ). Indeed Christianity always comes in as a critical voice in relation to 
an existing religion and cultural realities, with which it enters into a complex process of negotiation. From this understanding it becomes clear that although Christian faith is an important cultural factor that encourages debates on cultural practices and leads to the transformation of practices, etc., it is no 'culture' on its own, but can only be understood in relation to other cultural traditions. The process of negotiation performed by the Urapmin shows how the new practices and meanings are definitively different from the cultural expressions they stem from, but, at the same time, are only understandable from the original cultural context. This implies that Christian faith in a way presupposes a specific cultural context that is not Christian; it cannot function as an isolated cultural element but always needs a cultural surrounding to find its forms and expressions. From this understanding it is still possible to use expressions such as 'a Christian culture', as long as this term is not understood in an absolute way. Ultimately, all Christian cultures include cultural heritages of non-Christian pasts. For example, medieval Europe represents a Christian culture built upon Roman, Celtic, Germanic, and other cultures, that were not annihilated but converted and entered into conversation with. This therefore implies that the conversion process never comes to an end, but is an ongoing process.

This understanding fits the theological perspective of the Ghanaian theologian, Kwame Bediako, who builds on Harold W. Turner's understanding of the fundamental role of primal religions in shaping African Christianity. Comparing African Christianity with the early church helps to show that the adequate basis for understanding what is going on theologically is not the interaction between Western and African culture and values but "Christ ... conversing with the soul of Africa" (Bediako 1992, 6-7). This perspective is especially interesting to us because it pays attention to the activity of God in this process of conversion which fits our understanding of intercultural theology as explained in Chapter 2. Bediako interprets the development of African Christian theology in the post-colonial era as a search for identity. He himself wants to contribute in this search for an identity as 'African Christians'. Bediako deeply identifies as Christian and as African. He cannot step away from his African identity, because he experiences it (using a somewhat awkward term) as an "ontological past" in order to indicate that this past is not passé, but still part of the present (1992, 4; cf. Bediako 1984, 88). Yet, for Bediako these poles of Christian faith and African-ness are not of equal weight. He perceives himself first as a Christian and - though deeply - only secondarily as an African (Bediako 1992, 32 and 441). Therefore, both poles do not stand in an irreconcilable opposition, because the two are integrated through a process of 'conversion' through which the Christian finds a new identity in Christ (1992, 31ff). Bediako links the identity of the 
African Christian to the notion of the 'integrity of conversion', a notion he borrows from the mission theologian Kenneth Cragg: the converted person is the same 'I' before and after conversion, yet not without discontinuity and critical reintegration of the past (Bediako 1984, 88; 1992, 4; 1995b, 258; cf. Cragg 1980; Toren 1997). We recognise Robbins' notion of the Christian identity as consisting of an ongoing conversion in relation to a pre-Christian past and the surrounding world through which it necessarily relates.

Together, Robbins, Turner, and Bediako point to the crucial role of conversion for the understanding of interculturation. In agreement with Bediako, we underline the activity of God in the conversion. This means that transformations and changes are crucial markers that help to identify what Christian faith contributes and what God is doing culturally. However, these transformations are not just 'practical solutions'. Feierman and Janzen's example of the transformation of the understanding of illness and health in Botswana show that these transformations are processes that take time and that find their place in the dynamics of intercultural relations:

In Botswana, missionary healers of the early twentieth century learned to speak of the body in mechanical terms of digestion as a 'manufacturing plant' and the heart as a 'force pump', and this too, served to locate illness in the individual body (consisting of quasi-mechanical parts). This strategy did not, however, constitute a thoroughgoing attempt to secularize medicine, since illness was linked to sin and healing to God's mercy. The result was, however a transformation of older African ideas about links between illness and impropriety or hurtfulness. The key change was that the sinner as described by the missionaries, was an individual, extracted from his or her community...Christian medical treatment as extraction from community was, however, only a transitional moment.... In Botswana baruti, African evangelists, introduced group prayer for illness and 'dealt with troubled or sick people as members of the Christian community', in a way that had not been a part of missionary practice.

FEIERMAN \& JANZEN 2011, 242.

Characteristics of Interculturation in the Discourses on Science and Religion from Francophone Africa

The anatomy of the interculturation process that becomes visible in the discourse on science and religion among the groups studied allows us to note a 
number of characteristics of this specific process that may also shed light on comparable processes elsewhere.

First, we point to the triangular relationship in the interculturation process between Christianity, African traditions, and Western modernity. There have been multiple studies analysing the mutual transformation of the Christian faith and African traditional culture in the process of the encounter between African and Western traditions. For example, in the process, physical wellbeing has become a much more important component to the Christian message, while African culture has opened up to a catholic and missionary religion (f. ex. Magesa 2004; Brinkman 2009, 201-240; Omenyo 2002). The discourses studied have shown that modernity, or more specifically modern science in this case, becomes equally part of this interculturation process. African cultures encounter Western science, in a context in which this Western science is moving away from the French notion of laïcité. After all, the impact of laïcité in the discourses is limited and mainly indirect as we show in Chapter 5. Thus, Western science becomes integrated with other understandings of life such as in healing practices that combine Christian prayer, the modern hospital, and traditional African therapies. This is also the case at the university, where Western science is perceived as creating a privileged social structure in the lodges of the Free Masons and similar groups. Conversely, the scientific training of the students impacts their appropriation of African cultures. For example, they can deeply identify with their cultural background, yet criticize the secrecy attached to much traditional knowledge in light of the Western scientific ideal of public knowledge (see the comments of Emmanuel, second research session with students' group of Abidjan, Chapter 5 ).

Second, in the discourses studied, there is an ongoing critical reflection on how to best appropriate and evaluate Western science, received Christian traditions, and traditional ideas and practices (Wrogemann 2012). Of course, this critical reflection is provoked by the setting of the Group Model Building sessions, but, reading these dialogues, one has the clear sense of being invited into a critical reflexive process that has been going on for a long time. It would be wrong to suppose that this is the prerogative of students trained in a modern university with Western roots. For example, the interventions of the Bamileke in the Yaoundé group show how important education is for them as a group. At the same time, a lot of participants from nearly all the groups refer to the resistance towards science in their traditional cultures and in the churches. This presupposes different perspectives within ethnic and religious groups which is the result of a reflexive process that is an essential part of interculturation. Reflexive appropriation is therefore not the prerogative of the Western contributors to the contextualisation process. 
Third, we point to the proper place of Christian faith in these dynamics. The intercultural process becomes even more complex, but also richer, when we realise that the groups do not relate to Western science as Christians or as Africans, but as African Christians, thus allowing them insights that would not be equally accessible to other groups. These insights are obvious in their reflections concerning science as developed on the one hand on Christian foundations and on the other hand tainted by, and suspect because of, colonial history. For example, as argued by the academics from Abidjan, the criticism of Western scientific reductionism comes forth from what is seen as a typical African way of dealing with the spiritual dimension of life. This African dimension is combined with a typical Christian understanding of the Holy Spirit, who receives an important place in their scientific work. This is more generally visible in the way that the participants tend to identify primarily as Christians, secondarily as Africans, and least with modern science.

Through the lenses of Robbins and Bediako the crucial transformative role of Christian faith can also be traced. This principle is even expressed in the research sessions. Enow, a theology student from Yaoundé, argues that the Bible receives a special place because it 'criticizes all cultures', including European and African ones (see Chapter 4 and P19, 31). More generally, the discourses reveal that a completely secular understanding of science, as received through education at a secular university in a laïcité context, is transformed into a deeply Christian understanding in which science itself receives an important position as a place of revelation - at least in the academics group from Yaoundé.

This brings us to a fourth point. The focus on transformation also helps us to see how this Christian understanding makes God a participant in science; not only indirectly, as revealing through nature the Divine greatness and wisdom, but also directly, when God is understood as the real Scientist. In the words of Clément, the chemist from Abidjan: we just interpret, God really knows. Yet, also in human science, which is more limited, God's activity is leading. The academics, and especially those from Abidjan, made it clear how they understand their academic work as guided by the Holy Spirit (Chapter 5). This Christian engagement also underlines the personal approach. The scientists' struggles and solutions are also revealed when God's active participation is taken into account.

The attention paid to the role that God plays underlines what we mentioned in Chapter 2 about the role of culture: "everything is culture, but culture is not everything." In the discourses we studied, culture does not dominate the whole perspective; there is ample room for Divine action. The conversion of culture therefore reveals the activity of God. 
In the foregoing section, we explained that we are specifically interested in transformations of cultural patterns. As science in its nineteenth-century Western understanding is a typical modern phenomenon, we now focus on the significance of these discourses for the study of the global spread of Western modernity. The central question is therefore to what extent the discourse on science and religion in these three cities points to the presence or possibility of a parallel or alternative modernity. The notion of 'modernity' is of course used in multiple fields and may point to different realities when used in varying contexts such as in modern social relations, modern art, or modern theology. Modernity, as a broader concept for a social constellation, has many dimensions. Modernity gives science a specific place and authority. In Chapter 5 we argued that this position makes it prone to develop further toward cultural scientism. Therefore, in the context of this study the question is whether the approach to science and religion in the studied discourses might present us with a competing or counter-modernity, and whether this invites us to critical theological reflections on the way the science and religion debate has been framed in the modern North Atlantic world. This will also lead us to discussions concerning cultural hybridity, a related term used by the research population.

\section{Parallel or Alternative Modernity}

In an overview article, Bjørn Thomassen (2012) distinguishes a range of terms used in the debate on modernity in cultural anthropology. Terms like 'multiple modernities' or 'parallel modernities' stress plurality and do not make one form of modernity (i.e. Western) the standard as terms like 'alternative' or 'competing' or 'counter-modernity' do. Yet, for the analysis of the discourse studied, 'alternative modernity', or a parallel term, is more adequate because the students and academics concerned are not developing a parallel modernity in isolation from the West, but are consciously and constantly referring to Western modernity, which they experience as a mixed blessing. It is not the case that they simply find themselves in a world of global flows in which some modern influences might be Western while others come from other origins. Modernity is predominantly perceived as a Western cultural reality that bears positive and negative consequences. This ambiguous attitude towards Western modernity is most evident in the discourses of both the students and academics in Kinshasa but can equally be detected in Abidjan and Yaoundé. 
Amongst the academics in Kinshasa, the critique of 'modernité' in a very broad sense was, for example, related to a link between modernity and certain moral problems evidenced on billboards and in slogans promoting beer and encouraging new relationships between the sexes. ${ }^{2}$ More important for our discussion is the equation of modernity with reductionist attitudes towards realities that do not take the spiritual world into account, such as in the practices of education as confirmed by the academics from Abidjan (Chapter 5 , second session). In the group of academics from Kinshasa, the medical doctor, who turns to prayer when she suspects a spiritual cause behind an illness is therefore praised for her willingness to go against what is perceived as a negative side of modernity. ${ }^{3}$

However, the attitude towards modernity is not entirely negative. Especially in the discourses from Kinshasa on the criticism of modernity, we have several appraisals of the blessings of modern life. In practice, the students and academics embrace many of the gifts of Western modernity, as is clearly expressed by the students from Kinshasa (see Chapter 5,). They live their lives in modern urban centres, using modern technology and transportation. On a more philosophical level this is worded by the noteworthy voice of Augustin, the Roman Catholic philosopher. He pointed out that many modern values, such as equality ('égalité) have Christian roots and that in that respect the problem is rather that we do not practice them enough. ${ }^{4}$ In this respect, the discussion of the notion of freedom ('liberté) amongst the students in Abidjan is interesting. In this African city, deeply influenced by modern France with its values of 'liberté, égalité, and fraternité' (freedom, equality and brotherhood or fraternity), this could easily be seen as a modern value, but instead here it is closely associated with the Bible: it is a fruit of the Bible that people are liberated from various enslaving traditional African customs. ${ }^{5}$

2 P12, 127 : "Les sociétés, les entreprises, les publicités en quelque sorte, ça réduisent aussi la foi aujourd'hui à l'église; quand je regarde les tableaux qu'on est en train de placer euh, les publicités, il y a des termes et des slogans $(\mathrm{xxx})$ la tradition $(\mathrm{xxx})$ parce que ça a une signification péjorative et puis tout a $(\mathrm{xxx})$ on voit l'homme, on voit la femme, on voit la bière et puis va tout temps $(\mathrm{xxx})$, voyez c'est la modernité qui nous a amené ça, en quelque sorte qui est en train de détruire."

3 P12, $68:$ : [...] Et ce n'est plus la médecine, ce n'est plus la science et au contraire c'est euh la foi en Dieu, la croyance et euh le médecin après avoir utilisé la modernité et les instruments tout tout tout et tous les examens, il n'a rien trouvé, c'est qu'il faut des brides à la foi pour que la personne soit sauvée et quand il a résolu ce problème de cette manière, la solution a été trouvée. Donc science oui mais dans la foi, on peut toujours réussir."

4 P 12,128 : see Chapter 5 , footnote 55.

5 See also the model built by the students from Yaoundé in the Annexes (figure YS2), which relates the Bible positively with liberty and relates liberty negatively with African culture. 
The question of whether these discourses present us with an alternative modernity leads us to the question of hybridity, a notion central to postmodern understandings of culture in a globalising world (Tanner 1997, 57f; Schreiter 1997, 74ff). The cultural formations represented in the intercultural interactions in these discourses are obviously hybrid in a weak sense: they are new cultural constellations that develop at the confluence of different cultural inputs. The question is whether they are also hybrid in a much stronger sense: do they represent dual religious or dual (and in this case possibly triple) cultural systems, in the sense that different cultural systems are practiced side by side without proper integration? Such double belonging can be discussed specifically in reference to religious belonging, thus leading to discussions of syncretism (Schreiter 1985, 146ff; Tan 2010). However, various cultural systems can equally exist together with people belonging to two cultural spheres that represent practices that are, or seem, mutually contradictory.

If the discourse studied here only presents us with dual or triple cultural systems that exist side by side without proper integration (what we would call 'strong hybridity'), the discourse could not present a view to an 'alternative modernity'. Hence, in that case Western science representing modernity would still stand relatively on its own without proper engagement with alternative insights and practices. From the perspective of certain radical atheist interpretations of science this would necessarily be the case. If, as Richard Dawkins claims, modern science has shown belief in God to be a delusion (Dawkins 2006), every combination of science with religious practices presupposing belief in God or spiritual beings in Europe, Africa, or elsewhere, would be expressions of a problematic junction between two irreconcilable thought systems. ${ }^{6}$ Yet, even from such a radical understanding, one cannot deny the possibility that in concrete lives, science, religious convictions, and certain cultural practices could exist side by side in unresolved tension or in uneasily separated compartments. Do the discourses encourage such an understanding, representing strong hybridity?

There is sufficient evidence in the discourses to counter such an interpretation. Take for example Espoir, a Pentecostal professor of mechanical engineering in Kinshasa, who suggests that this is a common view among many Africans:

6 Although most scientists and theologians involved in the science and religion debate would propose much less combative and exclusive relationships between science and religion, this is equally true for all approaches that presuppose a separation of science and religion. See for example the position of Taede Smedes, presented earlier in this and the former chapter. 
"(O)ur brothers, who have not had the possibility to study at the university [perceive us as] hybrids. We respect science on the one hand, but I myself still respect the tradition...I am convinced that I should pay the bride- price...I therefore have the tradition in me and I also apply science." Nevertheless, he does not agree that this constitutes a hybridity in the strong sense: "Me, personally, I don't see an opposition here ... evidently there are places where reconciliation is not possible [but] I have reasonably well reconciled even the science that I learned at the university, furthermore our traditions, family, and all such things." ${ }^{7}$ As the quote shows, the need for reconciliation is not just an intellectual need, but also a practical requirement.

\section{$8 \quad$ Alternative Modernity and Ongoing Conversion}

Let us return to the question of whether the discourse studied presents us with an alternative modernity. With respect to this study, the question can be narrowed down to: do these discourses present us with an alternative modernity in so far as Western modernity is shaped by a certain understanding, a certain practice, and a particular weight given to the modern science? Our material is too limited, and the social relationships in the cities studied are too much in flux, to answer this in the affirmative. We may, however, indicate a number of insights that point to alternative approaches to modern science that indicate seeds of an alternative modernity that may be taking shape. Finally, we will relate this approach to the perspective of Bediako and Robbins that we embraced above. We presume that the emphasis on conversion helps to find more specific aspects of the alternative modernity as presented in the discourses.

In the first place, science is presented as having a limited scope in the explanation of reality. To use the expression of Clément, the chemist from Abidjan: science is human interpretation, no explanation. This position wants to combine a respect for modern science with a non-reductionist attitude to reality that allows for the influence of both God and other spiritual powers on natural processes. Some might see this as an expression of a hybrid worldview in the

7 P12, 142 : "Donc ils sont perçus par les autres sont nos frères qui n'ont pas eu cette possibilité d'aller suivre les études à l'université donc on est comme des hybrides ( $\mathrm{xxx}$ ) la science, d'un côté nous gardons, moi-même je garde encore la tradition essaye de garder, $(\mathrm{xxx})$ je suis convaincu, je dois respecter la dot, il faut payer ce qu'il faut payer chez les hommes, donc la tradition je l'ai en moi, la science aussi je l'applique. Moi personnellement je n'ai pas, je ne vois pas d'opposition entre, en tout point évidemment il y a des points où on peut pas concilier, moi j'ai concilié assez bien jusque-là la science que j'ai apprise à l'université, puis nos traditions, la famille tout ça." 
strong sense: an effort to combine traditional African explanations of disease and other natural phenomena with natural explanations and treatments.

However, this combination leads to an alternative perspective to some Western understandings of modern science, such as a positivist orientated approach. For the research population, however, this does not represent a 'God of the gaps' view. Adama, a student from Abidjan, indicated that science itself is a gift of God who created this world with its natural processes. The openness to divine action is rather a consequence of a recognition of the multi-layered nature of reality, in which disease can not only have physical and psychological causes and solutions (as may also be recognised in Western medical science), but also spiritual ones (see Chapter 5 , cf. Hiebert 2009, 127-159). The question concerning this multi-layered quality of natural processes will therefore be part of the intercultural debate on science and faith.

We underline the specific relation of this understanding of the limited scope of science to its values. Incidentally, we do not deny that a lot of scientists from the North Atlantic might share this modest understanding of science, although this is not in line with the tendency towards scientism in today's Western societies. In the discourse, modern science is not treated as an independent value system, but as a reality to be appreciated and valued from a broader perspective, in this case from African Christian faith. These discourses reveal that in this context there seems to be more cultural and mental space for such a critical valuation than is the case in current-day North Atlantic cultures. The first reason that there is more space is given to the fact that science is more suspect as a cultural force because of its association with colonialism. The second is that the discourses seem to be devoid of scientism as a cultural reality. As we saw in Chapter 5, many Western Christians may deny 'scientism' as a philosophical viewpoint that makes modern science the norm of what can be known or even of what is real, but a cultural form of scientism is much more widespread. As we argued already, science takes on religious features. It is the starting point and the norm to which religion must in one way or another conform. The absence of this cultural scientism in these African discourses is, for example, shown in the models by the variables that indicate communal values. It allows for much more scope to evaluate science from a community perspective within an overarching, in this case Christian, framework and value system rather than the inverse. One does not need to be able to shape science entirely from a Christian perspective in order to live in this 'duplex cultural formation' (Robbins) with a coherent Christian identity.

Second, above we argued that the 'alternative modernity' approach can be distinguished from the one that focusses on 'hybridity' (at least in its strong sense) by the fact that the first proposes a different way of dealing with 
modernity than in the West, while the second points to the participation in two different cultural realms that exist together without an integrative perspective. We alleged that the way the discourses deal with science does not justify the conclusion of (strong) hybridity in the sense that the participants equally participate in a traditional African 'system' and in a 'Western' system. However, this last- mentioned possibility cannot be denied completely. For example, during the Group Model Building session in Kinshasa, the academics oppose the Western, scientific approach to the African approach, which is directly linked with Christian faith. Maybe because of this double perspective, in this group the concept of 'hybrid' was also used. The suggestion of this discourse is that as a scientist one participates in both. However, this tendency is not dominant. Also, in the discourse of the academics in Kinshasa, and even more outspoken in the discourses of the groups from Abidjan, the idea that Western science and Christian faith and African traditions are complementary, and part of a bigger unity, is dominant. This approach was qualified as typically African, particularly by the students from Yaoundé. In relation to the abovementioned distinction between alternative modernity and strong hybridity, we can say that the traces of strong hybridity in the discourses are not prevailing. Therefore, what is taking shape in the discourses points more convincingly in the direction of an alternative modernity. This is a direct consequence of the broad consensus regarding the option in which science and faith are understood as belonging to an overarching whole (see Chapter 5 ).

Finally, we point to the specific role of Christian faith in the way the different cultural influences are related. As indicated before, the three main influences, African traditions, Western culture, and Christian faith, do not exist together as equally important for the identity of the students and academics concerned. As became particularly clear in the discourse of the students from Yaoundé, at a conscious level the participants understand themselves primarily as Christian, and from this perspective they relate to their African cultural and religious traditions, and to Western scientific practices. It is important to note that this research took place in the context of GBU. This Christian environment has certainly influenced this outcome. Nevertheless, we think the underlining of the Christian identity is a genuine aspect of the debate. The complexity of their understanding of science and faith is not only because their Christian faith necessarily relates to a pre-Christian past. It is also related to the fact, noted by Robbins $(2017,47 \mathrm{f})$, that part of the Christian faith itself is the challenge to relate to a 'world' that does not share the understanding of life and the priorities that characterise the Christian faith. Above we quoted Robbins $(2017,40)$ when he states that Christianity as a religion sets up 'duplex cultural formations'. This is equally true for the students and academics in our 
sessions: they do sometimes experience the tensions with the surrounding world as difficult, but they do not consider this at odds with their Christian faith, but rather a part of it. The discourses from all the three cities show that from their African Christian engagement they criticize and welcome both Western science and traditional cultures. The discourse of the students from Kinshasa offers an interesting example of this because there is this double evaluation of traditional and modern techniques. The students and academics of our research live in much more open social environments than the Urapmin Christians of Robbins' research. Whereas the Urapmin Christians live most of their lives within a single village community in which most aspects of life are shared, the participants of this research live different aspects of their lives in different communities with their own value systems. Yet, the research does show that the intercultural relations between the three influences identified by the participants do not necessarily result in strong cultural and religious hybridity. On the contrary, the discourses of the groups attest to a search for an integrated and overarching Christian perspective that promotes an ongoing conversion of culture. The transformation, so typical of this perspective, that is proposed in the different groups concerns the understanding of the modern concept of science, more specifically as transmitted in the French notion of laïcité. From the perception of the research population, science should not be separated from the other domains of life but integrated in a broad perspective in which Christian faith and communal ethics play prominent roles.

\section{9}

Catholicity and Contextuality in the Science and Faith Debate

From the beginning of this study, we have indicated that we have engaged in this exploration in order to allow the voice of French-speaking Africa to be heard in the global science and religion debate. And, because this global debate is so strongly dominated by North Atlantic voices, allowing this particular voice to be heard contributes to the deconstruction and reconstruction of the North Atlantic debate as culturally located.

Nevertheless, it is not obvious that contributions from such a particular cultural and geographic setting can be heard in the global debate. The difficulty of setting up such a conversation may well have roots in characteristics on both sides of the intended conversation, as the final section of Chapter 5 suggests. We can point to the academics who are used to the universalist language of scientific discoveries and the universal truths of religion on the one hand and the historical and anthropological approaches that locate the science and 
religion debate in particular contexts on the other. In the next chapter, we will situate our research in between these two tendencies.

From our understanding, the catholicity of both Christian theology and the scientific enterprise in general is therefore crucial: insight gained within specific historical settings and unique laboratories are shared 'with universal intent'. In the final section of this chapter, we build on the value of intercultural theology as introduced in Chapter 2 for the understanding of our research, precisely because of its reflections on the particularity and catholicity of theology. This will also deepen and flesh out the understanding of intercultural theology introduced in Chapter 2 by asking what understanding of intercultural theology can do justice to these discourses and their contribution to a global intercultural theological exchange.

As indicated, the participants of the discourses were well aware of the impact of the different aspects of the cultural setting and 'force-field' in which it took place. Yet, in this field, they identified foremost as Christians. This understanding facilitates the role of Christian faith as transforming culture, which we developed above with the help of Bediako and Robbins, and this is central to our understanding of intercultural theology. The participants' reflection on their identity is closely related to what Bediako wrote about Christian identity. In his understanding, this identity relates to the decisive events of Jesus of Nazareth's crucifixion and resurrection, which revealed his 'universal significance' as the Son of the God and the Saviour of the world (Bediako 1996, 38). This reference to Jesus of Nazareth therefore plays a similar role in his understanding of his African identity as to that which the Bible plays in a number of the discourses that we studied: it is the vantage point from which all other cultural expressions are critically judged and given their place. The universal meaning of the Christian faith is therefore not given with some presupposed position or anchor outside of culture or history, but because this one person, his death and resurrection, and the Scriptures that testify to these events, are believed to be of universal significance. The consequence of this highly personal and historical focus makes the cultural location of theological reflection not only important in relation to the content of the Christian message and the specific thought forms used to express it. It is also culturally located because Christian theology comes forth from Christian praxis and is directed toward praxis.

Intercultural theology is therefore concerned about faithful performance and faithful speaking and thinking (see Vanhoozer 2005 for example). It is 
concerned with wholesome living and this wholesome living has contextual traits in that it aims to work itself out in a variety of contexts addressing multiple contextual challenges.

From such an understanding, Christian theology, and more specifically intercultural theology, is by nature catholic in its intention as well as in its local expressions. We understand local theological conversations as part of a global exchange within the worldwide church in which they draw on insights from others, and themselves contribute to wider conversations, in order to arrive at a growing understanding of God and God's relationship with humanity. Christian theology is also catholic in an even wider sense, since, because Christians believe that God's love is directed to the entirety of humankind, Christianity is a missionary religion that is intent on sharing this message universally. ${ }^{8}$

Yet, for the crucial importance of the historical and local persons and events, though Christian theology is catholic in scope, it is at the same time deeply culturally rooted and therefore contextual. Just the central belief in Jesus Christ as Lord was initially expressed in the conceptual framework available in Second Temple Judaism. From there, its message was soon translated into other culturally embedded languages and conceptual frameworks, such as the koine Greek of the Hellenistic world. When Jesus of Nazareth was proclaimed in the Hellenistic world, his title Messiah - or Christos in Greek - did not make the same sense and have the same appeal as in the Jewish context. Thus, the title kurios, or Lord, became more important. This amplified the message proclaimed but, at the same time, influenced the meaning of kurios. Now 'lordship' could be used with reference to Jesus of Nazareth, it could acquire new meanings that it did not have before. Beforehand, it was inconceivable to think of a Lord who reigned from the cross or whose lordship included authority over death. During this process, the Christian message also took on new meanings, but in theological reflection, these languages itself were fine-tuned so that they were better able to express the unique message they had been used to articulate (Toren 2011, 175-177).

As Andrew Walls, the historian of mission and non-Western Christianity, famously expressed, Christ himself 'grew' in the process of cross-cultural translation (Walls 1996, xvii). This is not only true in the sense that his influence grew, but also in the sense that the salvation He brought took on new meanings. From a critical realist perspective (see Chapter 2), this means that when new languages were used to reflect on his person this led to new insights into who He was and what his salvation meant that were not possible beforehand.

8 The intention to share universally, however, is not unique to the Christian faith but is shared by other world religions as well (Griffiths 1988, 403ff.). 
An example is the formula from the Council of Chalcedon in A.D. $45^{1}$ that states "that our Lord Jesus Christ is one and the same Son; the same perfect in Godhead and the same perfect in manhood; truly God and truly man" (Olson 1999, 231). These insights into the unique nature of Christ would not have been possible in the Jewish conceptual forms of the first Christian community and have enlarged the understanding of who He is.

In the case of an intercultural debate on science and religion, theological reflection needs to be aware that 'science' and 'religion', as we have seen, are themselves culturally shaped concepts (Asad 1993; Auffarth and Moher 2006; Bagir 2015; Harrison 2010). The way these concepts are shaped in the North Atlantic world may be insightful, but when these terms are translated to approximately comparable terms in other cultural contexts, this contributes to the diversification of the understanding of the terms (Livingstone 2011, 287). Due to the use of French, there is no major impact of translation in our research, but the use of the concepts in French-speaking Africa show certain limitations of the North Atlantic debate - as well as characterize the discourse that is currently taking shape in French-speaking Africa.

Therefore, intercultural theology needs to ask how to respond to culturally specific challenges, such as, for example, the challenge presented by cultural scientism in the North Atlantic world or the challenge of relating this debate to thequestfor Africanidentityin French-speaking Africa.Themutualconversation between those contexts on the one hand reveals the cultural specificity of these challenges. By revealing their cultural specificity, it relativizes these challenges and points to new answers that might otherwise have remained beyond reach.

An example of the way that understandings of religion are shaped by the Western context can be found in Ustorf's perspective on intercultural theology. In the understanding of intercultural theology held by Ustorf and his teachers, Margull and Friedli, we see an openness for transcendence, but a reluctance to commit to any particular religious tradition. Consequently, this perspective integrates "a strong dosage of [...] modern occidental agnosticism and relativism into the mix of intercultural theology" (Ustorf 2008, 242). In our opinion, this starting point reveals that this type of intercultural theology is a Western or even European project, as these representatives themselves also recognize (cf. also Küster 2011, 110). This Western view allows little space for the idea that different Christian theologies are also responses to the self-revelation of God in the Christian Scriptures and, as such, is contrary to the theological positions of most of the participants in our research. The more consistently catholic and post-colonial approach to intercultural theology we use and develop in this study means that we cannot at the outset write these positions off as entirely 
relative due to their deep cultural embeddedness. The intercultural framing of the debate in the discourses showed that the participants were aware of their cultural location, but, contrary to Ustorf, they would not accept that their confidence in Christ and in the Christian Scriptures was equally relativized by this location. From our perspective, a truly intercultural theology demands that the question of the way in which, and the degree to which, culture shapes theological positions is itself part of the intercultural exchange and not foreclosed a priori. Whether theologically one ultimately does better justice to the divine with a generalised notion of transcendence, as in Ustorf and others, or with an historical understanding of God's self-revelation, as expressed by Bediako and reflected in the discourses, would demand extensive theological debate beyond the confines of this study (see, for example D'Costa 1990; Toren 2011, 204208, passim) in which we would more closely align with Bediako and similar positions.

\section{The Postcolonial Condition}

Intercultural theology has significant overlap with postcolonial theology because of the joint interest in the cultural and social location of theological reflection (Hof 2016, 65-72). It may also be considered a school within the field of intercultural theology, because it works with an understanding of culture as diverse. "In postcolonial theory culture is not understood in terms of ideas and objects, but principally as a ground for contest in relations....Culture is something to be construed rather than discovered, and it is constructed on the stage of struggle amidst the asymmetries of power" (Schreiter 1997, 54; cf. Bradnick 2012). There is, however, an important difference here between the way we perceive culture and this postcolonial perspective. We take culture as a given that is being transformed by the influence of Christian faith. The perspective here is that of an individual or that of a local community, as is exemplified by the research of Robbins. Post-colonialism, however, focusses on the (societal) structures of power that facilitate culture and culture making. This fits with some important elements of discourse analysis used in social sciences, as we discussed in Chapter 2. Here we also explained our objections against a constructivist understanding and the totalitarian outlook it can produce. Nevertheless, postcolonial analysis is useful to us. Furthermore, from our understanding, power is also a crucial category in the maintenance of the status quo as well as in its transformation. From a theological point of view, divine power is also included. We therefore think that the analysis of the power play in a 
concrete society or community is an indispensable part of doing intercultural theology, as the participants in our research also testify, and as we argue below. After all, we live in a world that is very deeply affected by colonialisms, especially those from the North Atlantic world. Yet, even the term 'French-speaking Africa' in the title of our project is filled with colonial and post-colonial meaning, as we summarized in Chapter 3.

The discourse studied shows the importance of postcolonial analysis for the science and faith debate. The students and academics are well aware of the power struggles involved. The groups from Yaounde underlined that Western science is a colonial force that leaves little space for a specifically African and African Christian approach to science (see Chapter 4). At the same time, there is a broadly shared suspicion or awareness of local power games: of secret societies that control university power politics (in all three cities), of Africanist pressure groups (academics from Abidjan), of churches that are worried about the influence of academic study on their members (in Abidjan and Kinshasa), and of students and academics who use academic education and jobs as a means of social advancement (in Yaoundé and Kinshasa). The positioning of the Bamileke participants we mentioned in Chapters 3 and 4 deserves a special mention here. This case shows that being involved in science and education also serves a political aim. There is no doubt that religion and thus the concrete choice of being a Christian is also influenced by certain power structures in society. Also, divine power is explicitly taken into account. The liberating power of the gospel received a crucial position in the model of the students from Yaoundé (Chapter 4). And the guidance of the Holy Spirit is a fundamental empowering element in the understanding of science by the academics from Abidjan.

As we will see in the next chapter, these themes are not very common in the North Atlantic debates on science and religion, and therefore this awareness of power-struggles can deepen Western science and faith discussions where the discussion of the influence of academic power structures is mainly used by those who take on minority positions that are excluded by the academic majority. Though more study might be needed here, it seems that such analysis is suspect to those who want to stress the trustworthiness of scientific discoveries and do not want to play into the hands of the religious and sometimes fundamentalist sceptics of mainline science. The discourses thus point to an approach that critically asks where power interests might obscure the clarity of scientific insight. They also point to the possibility of including the mention of the divine presence as an enabling power in an existing cultural setting. Therefore, these discourses also challenge the repertoire of most postcolonial theologies that focus on marginality and vulnerability (Hof 2016). Although 
human power in this approach is justly questioned and criticized, the positive (use of) power in the light of the kingdom to come remains neglected.

\section{Intercultural Exchange between Different Culturally Embedded Discourses on Science and Religion}

Given these considerations from intercultural theology, we now look at the debate on science. Several times in this study, we have pointed to Thomas Kuhn's The Structure of Scientific Revolutions (1962) which has greatly contributed to the awareness of the importance of social location for scientific inquiry. What scientists consider convincing will be profoundly shaped by the dominant scientific paradigms that govern which questions are asked, what type of theoretical solutions are sought, and even what counts as relevant data. Some radical followers have concluded that scientific pictures of the world are therefore mere social constructions. Kuhn himself was much more nuanced, realising that socially located scientific traditions are engaging with nature; that scientists cannot simply 'beat nature into line', and that it is resistant to our interpretations (Kuhn 1996, 135, pp. 52ff., 96ff., 206). Yet, Kuhn stressed the 'incommensurability' of research paradigms, a term with which he indicated that there was no perspective independent from such all-encompassing paradigms that would allow for a rational comparison of the paradigms itself.

One promising way forward is to think of science as being shaped by 'research programmes' (Imre Lakatos) or 'research traditions' (Larry Laudan) (Murphy 1990, 51ff.). According to Lakatos, different scientific perspectives are embodied in research programs from within which scientists study the world. A research program centres around a main theory (a concept which we might link to Kuhn's 'paradigm') with a number of auxiliary theories around it through which the world is studied. Research programs are successful or 'progressive' in as far as they continue to grasp an increasing amount of data and allow for the development of new auxiliary theories that can deal with these increased data or with anomalies that appear and that might at first seem to invalidate the central theory.

Degenerating programs can only preserve their core theories by ad hoc adaptations of their auxiliary theories. Competing research programs can therefore be compared in terms of their progress, which thus becomes a measure of how well they can cope with reality as it is in itself, taken independently from the theoretical framework we use to look at it (cf. Brink 2009).

Lakatos' concept of competing research programs presents us with a model that allows us to study the interaction between different culturally and socially 
embedded research traditions. It moves beyond Kuhn in that it does not focus on the dominance of one paradigm that may in due time be exchanged for a stronger competitor, because Lakatos' model would allow us to value the existence of several parallel research programs, including marginal ones. The science and religion debate adds extra layers of complexity. The science and religion interface is concerned with overall conceptions of the nature of science. While research programs are characterised by scientific theories and scientific practices, particular research programs may well be combined with various overall conceptions of the nature of science, that are themselves also embedded in broader cultural and philosophic traditions.

As we have noted before, the concept of religion itself is profoundly shaped by different religious traditions in their interactions with their cultural environments. One can well speak about traditions of research concerning the science and religion interface that work with fundamental theories about the relationship between science and religion, such as the models distinguished by Ian Barbour (Barbour 1997, 77-105). These models are each at the origin of different research traditions. However, in Chapter 5 we already explained that these models, all rely on the modern Western understandings of science and religion, and the discourses studied here point to possible alternative research traditions.

Using Lakatos' model of competing research programs, one could easily conclude that the traditional African approaches to healing - which so deeply integrate what Westerners call medical practices on the one hand and religious practices on the other that they cannot be properly distinguished (Feierman and Janzen 2011) - are in a deadly struggle with modern Western approaches to health and healing. One could in the same vein conclude that the first intimations of a specifically African Christian approach to science and religion, which are discussed in some of the final focus group sessions, do not have the momentum and/or institutional support that would allow their development into a research program. On two counts, this analysis will need to be deepened and nuanced.

First, with insights from postcolonial theory, one would ask whether the relative success of programs might well be related to the political and social support they receive, rather than to the inherent progressive nature of the program. From this perspective, certain marginal or subaltern voices might well need to receive specific attention because they may represent creative critical insights that the voice of the majority drowns out to its own loss. From an intercultural perspective, one would also ask whether certain central or auxiliary theories are given higher credentials than they deserve because they ring true within a specific culture. 
Secondly, the insights from traditional Africa and from African Christianity are not neatly separated into research traditions. The analysis of the discourses points to intercultural interaction in which the influences of Western science, Christian faith, and pre-colonial African traditions are all changed, allowing for new cultural configurations that could not have come into existence if one of these streams had developed independently. All Christian traditions show such amalgams that have proven hugely creative and successful. This fits our understanding of culture which we defended above. The critical cultural interaction between the earliest Christian faith developed in a Jewish context and surrounded by Hellenism, and the later interaction between the Latin Christian tradition and the culture of the Northern Germanic tribes, and the most recent interactions between modern missionary Christianity and African primal religions - leading to African independent Churches and neoPentecostalism - are all examples of this (also see Chapter 3). It is our contention that the approach to science and religion expressed in the discourses studied, which so far has remained marginal, may well contain the seeds for an alternative Lakatosian 'research program' on science and religion that provides crucial contributions to a catholic debate on science and religion.

Looking at these complex cultural interactions, the joint and closely related attention that intercultural theology pays to both contextuality and catholicity invites us to propose a number of principles for navigating the tension between these two poles, in relation to both a broader intercultural exchange in general, and to science and religion in particular.

- In the first place, the notion of catholicity in theology cannot be separated from a basic confidence that God can be known even though humans are limited by their historical and cultural locations. This theological principle is directly related to the fundamental trust, on which other sciences are similarly based, that reality can be known. This trust is confirmed in the research process itself but remains essential to the process. The science and religion debate can similarly be engaged on the basis of a joint confidence that an open inquiry may lead to an increased understanding of the matter.

- Secondly, the notion of catholicity brings a normative element to the attitude proper to this inquiry, because it requires an attitude of receptivity. It nurtures humility towards the reality of God, the other, and nature itself. The catholic approach we propose combines an awareness of the (inter-) subjectivity of knowledge, with the effort to let these other realities speak for themselves.

- Thirdly, the notion of catholicity is richer than a reference to the universality or the 'universal intent' of scientific research. It not only places science in 
the context of research communities, but in a 'community of communities'. The worldwide Christian community can only be catholic if it incorporates and listens to the voices of many culturally embedded Christian traditions. It envisages an intersubjectivity that is as wide as the global body of Christianbelievers. Similarly, the science and religion debate needs to be catholic in the sense that it consciously engages in a dialogue with a range of culturally and religiously embedded perspectives (Christian, secular, and other voices) that can each contribute their proper perspectives and insights. Other cultural perspectives may allow one to positively contribute insights that would otherwise be impossible or very unlikely.

- Fourthly, an intercultural approach would ask whether such an intercultural exchange might reveal blind spots to particular culturally embedded approaches. Are there either culturally shaped mindsets (such as methodological naturalism) or social pressures (such as cultural scientism) that function as a screen that hinder us from putting certain characteristics of the science and religion debate in a particular context into sharper focus?

- Fifthly, an intercultural approach would not simply ask for the most competitive research programs. It would ask whether weak and even marginal voices need to be brought to the fore where they risk being drowned out by more powerful players and traditions. This reflects the sensitivity of postcolonial analysis. Yet, these voices are not considered valuable because they are marginal, but in so far as their marginality allows them to perceive aspects of reality and of God that risk being drowned out by more powerful discourses. In the sixth place, intercultural theology is aware that formal academic theology is not the only voice worth listening to. It will also gather insights from what might be called 'espoused theology' or 'lived theology', just as we have been gathering insights from the lived engagement with science and religion in French-speaking Africa (see Chapter 2).

- Finally, an intercultural approach to science and religion also needs to respect the specificity of every context and therefore asks whether certain challenges demand context-specific answers. 